\title{
HERITAGE ARCHITECTURE AS DOMESTIC SPACE: A TALE OF THREE BUILDINGS IN ILE-IFE, NIGERIA
}

\author{
C.O. OSASONA \\ Department of Architecture, Obafemi Awolowo University, Ile-Ife, Nigeria.
}

\begin{abstract}
Ile-Ife, the ancient city symbolizing the very essence of Yoruba ethnicity is, expectedly, culturally significant. Much has been written about its naturalistic bronze and terra-cotta statues, as well as its festivals and other ritualistic engagements. However, the city's architectural heritage - encompassing traditional, colonial and colonially facilitated archetypes - is yet to be significantly documented. The paper seeks to showcase some of Ile-Ife's building heritage, focusing on three houses, built in the Brazilian style, which typify the essentials of the style. Apart from the characteristic architectural features depicted, they also typify the unfortunate trend of benign neglect - increasingly the fate of such buildings in Nigeria. Additionally, the case studies presented have the phenomenon of being currently occupied in common - despite their dilapidated condition. The paper discusses the issues generating the paradox of heritage architecture being left to decay, yet constituting treasured domestic space. It is submitted that the relatively undeveloped state of architectural conservation in Nigeria is responsible for the sharp dichotomy between heritage architecture being either icon or home; elsewhere in the world, it has been possible to combine both - to the optimum advantage of the building.

Keywords: Heritage architecture, architectural conservation, Ile-Ife, traditional Nigerian architecture, British colonial architecture, Brazilian architecture, domestic space, perception of space, tourism potential of heritage architecture, architectural icon.
\end{abstract}

\section{INTRODUCTION}

'Heritage' is generally understood to mean something that accrues to one by virtue of birth, through legitimate inheritance. It could, therefore, be material possessions or more generally, a body of tangibles and intangibles defining one's lineage, history or general identity. Architectural heritage, therefore, more specifically refers to the body of built structures that culturally locates a people, presenting their experience (vis-à-vis styles, materials and techniques), particularly in a historical context.

Every culture, regardless of the current stage of 'civilization' (or urbanization, as it is more commonly called today), has a traditional past. By this is meant a period in their history when they were much less sophisticated and closer to nature than presently. As such, the starting point of the architectural heritage of any people is invariably the traditional, necessarily leaning heavily on locally available, simple materials, to generate uncomplicated built form; the Nigerian experience is no different. The local architectural heritage encompasses the traditional building culture as well as what it progressed to be, after it was impacted by other influences (such as the Arabic in the north, and the later British colonial, generally all over the country).

\subsection{Nigerian heritage architecture}

Nigeria is a country of great diversity. With a population of nearly 160 million, it should not be too surprising that it has over 250 ethnicities, speaking about 350 dialects. Religious diversity is generally sympathetic to a north-south dichotomy, conferring an Islamic status on the North, and Christianity on the South; however, the divide is not as rigid as it would immediately appear, as there are substantial numbers of both religious inclinations inter-mingled with either. More of a 
determinant of the traditional built-form than religion are the issues of climate and local terrain; these have inter-played to influence local materials available for building, techniques used and forms generated.

Historically, the country has undergone much political restructuring. Initially, living as various ethnic groupings loosely bonded by trade and other exchanges, it underwent colonization under the British and, in the wake of the liberation struggles that swept over the African continent in the midTwentieth Century, gained independence in 1960. The various issues building up to the scramble for West Africa (particularly) and the specific socio-political impact on Nigeria, are well captured by Fajana [1] and other historians. Suffice to say that, despite the fact of the British ostensibly taking their leave in 1960, the country, till date, has an abundance of tangible legacies harking back to that era. These range from buildings directly constructed by them (to service the colonial agenda), to those whose construction they facilitated; specifically, the latter refers to buildings erected by emancipadoes from Latin America, and those by the saros from Sierra Leone.

\subsubsection{Traditional building in Nigeria}

The commonest building material is earth; this was traditionally expressed as either monolithic layers of cob, adobe (or terra-cotta) or wattle-and-daub construction. Roofing could be similarly of earth (in the northern areas using shallow-domed roofs and vaults because of relatively little rain) or of vegetable matter over a timber framework. For reasons of inability to cope with large spans (due to lack of iron reinforcement) and environmental control, such openings were characteristically under-sized; eaves were also pronounced to facilitate sun-shading and general protection of walls. Such structures dotted more than $60 \%$ of the traditional builtscape.

In parts of the country where a rocky terrain predisposed, stone walling (covered with a conical thatch roof) provided the prevailing archetype. Where an abundance of grass was available (such as in the Sudan Savannah area), it could be woven to produce matting for fence-walling, as enclosure for buildings of more substantial material. Swampy terrain automatically generated lightweight architecture using bamboo for walling and palm fronds for roof-cladding; such structures were supported above the marshes on stilts. Similarly, lightweight architecture (but predicated on impermanent materials such as stalks of sorghum) was used in parts of the Sahel Savannah region of the country (see Figs 1-5).

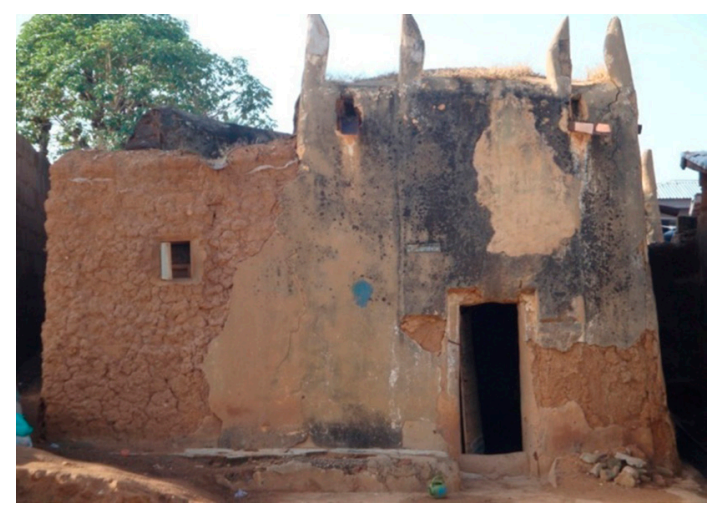

Figure 1: Typical Hausa architecture. Zaria, northern Nigeria. (C. O. Osasona, 2009). 


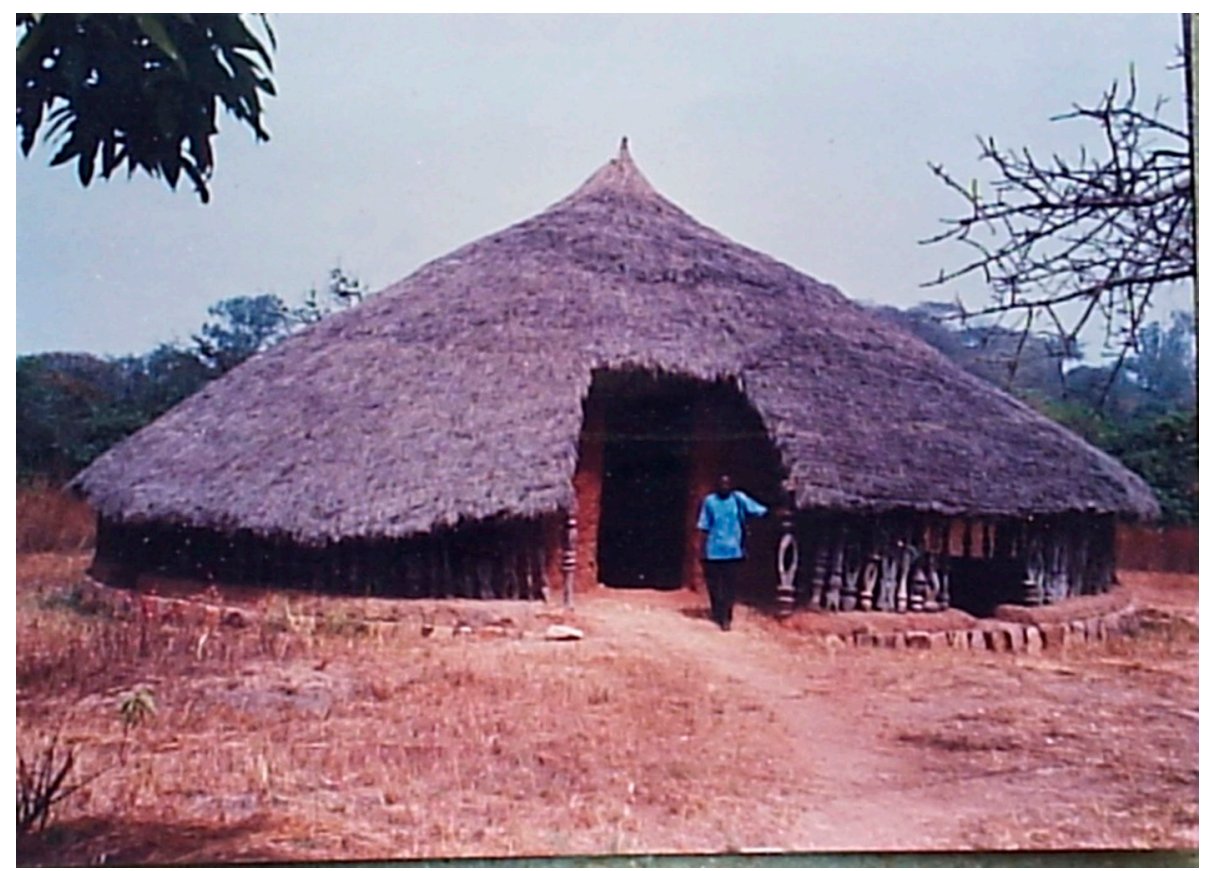

Figure 2: A reception hut. Nupe architecture. Middle Belt. (C. O. Osasona, at Museum of Traditional Nigerian Architecture, MOTNA, Jos. 1993).

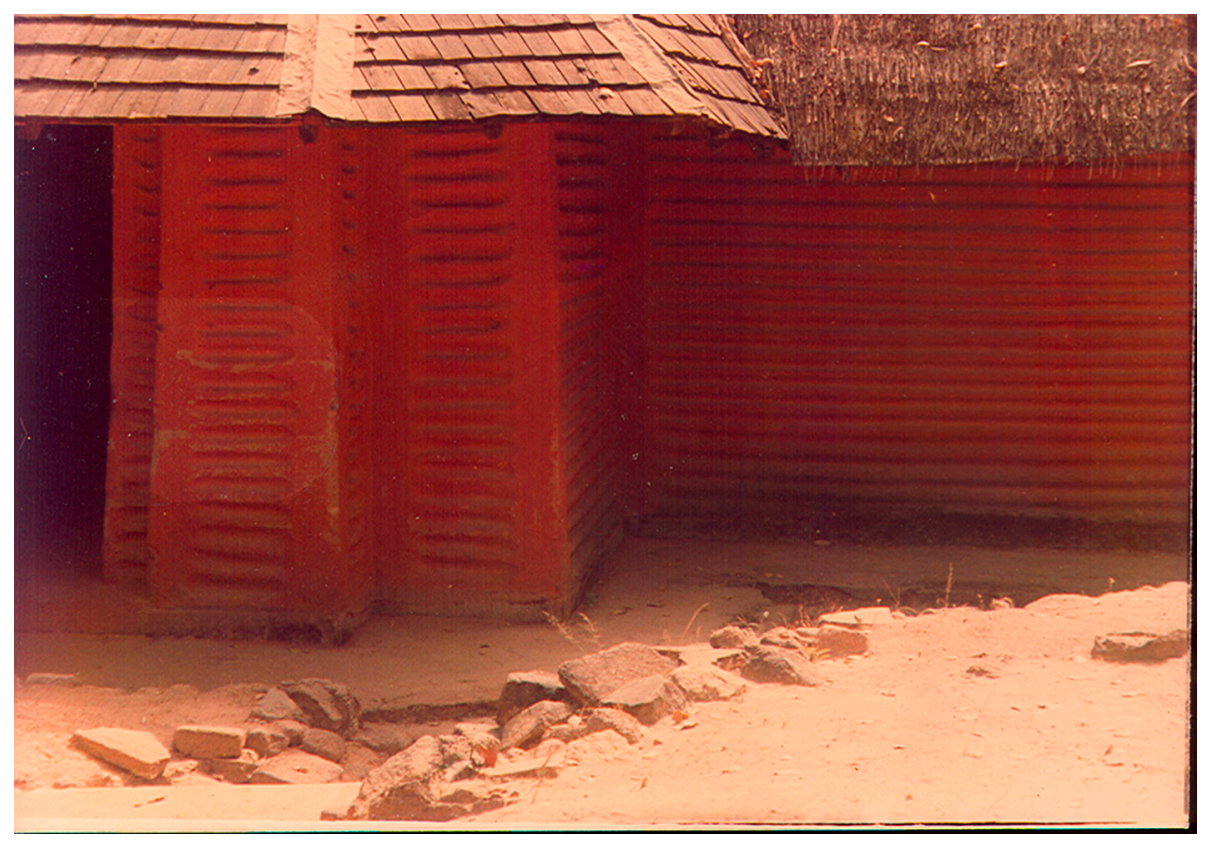

Figure 3: Bini (Edo) architecture, of Mid-western Nigeria. (C. O. Osasona, MOTNA, Jos. 1993). 


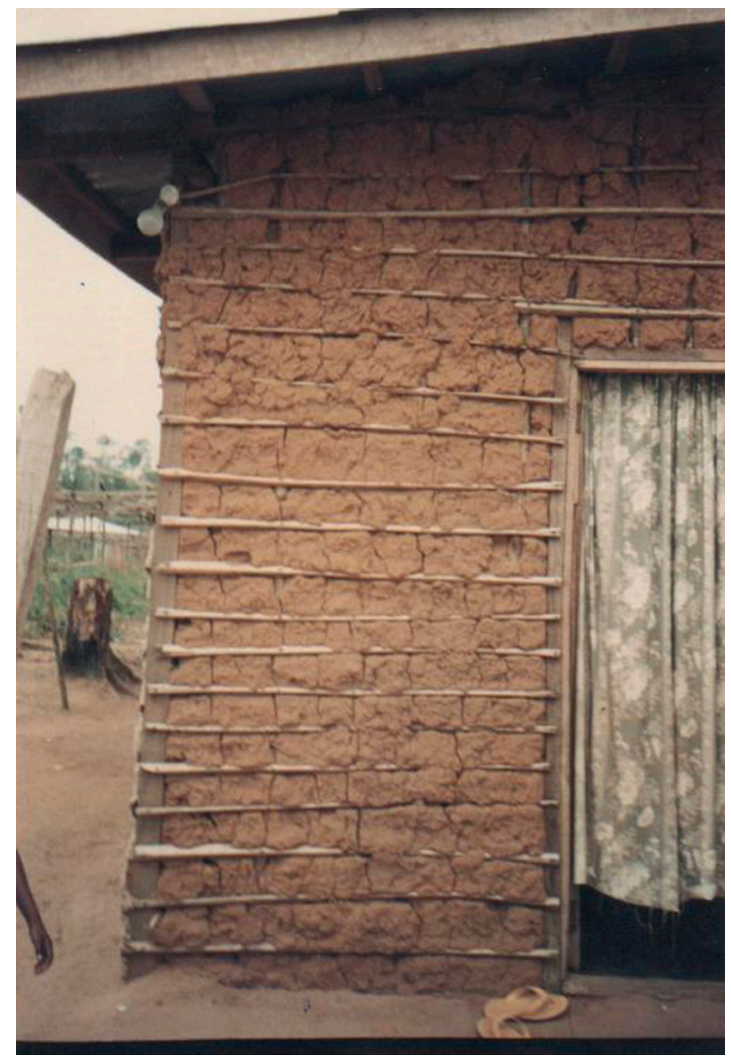

Figure 4: Wattle-and-daub construction. Eastern Nigeria. (E. Ikhuoria, 2007).

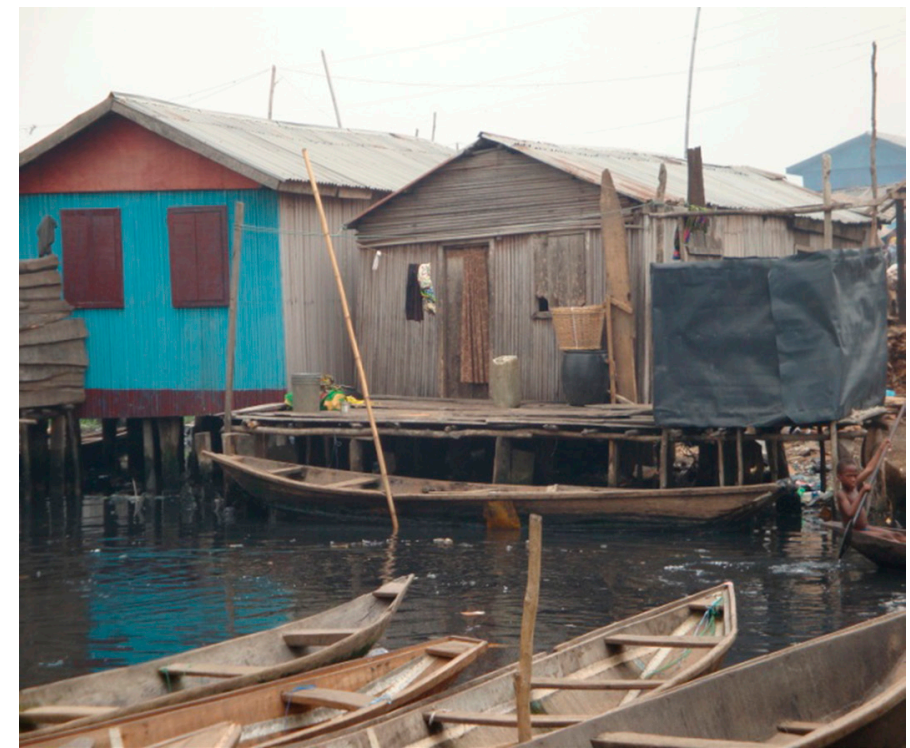

Figure 5: Riverine architecture. Makoko, Lagos; creek area. (C. O. Osasona, 2009). 


\subsubsection{British colonial buildings}

These had to meet both the social needs of colonial administrators, as well as withstand the peculiarities of the tropical setting. From the original, virtually direct transplants from the United Kingdom, colonial building metamorphosed to what, today, is acknowledged as 'tropical architecture' - an authentic forebear of both modern architecture in the country, and today's contemporary architectural practice. Though much of this building type wore a residential aspect, city halls were intentionally massive and generally overbearing - depicting 'architecture of power'. Materials encompassed burnt brick, stone (and later, sand-cement blocks) for walls; shingle tiles (later corrugated metal sheets) for roofing, and tiles and synthetic paints for wall- and floor-finishing.

Later tropicalizing elements on colonial buildings included sun-shading devices (such as window hoods, fins, pronounced eaves and the use of verandas); an east-west orientation for the shorter side of buildings; fenestration to ensure cross-ventilation and rapid air changes; exaggerated indoor headrooms to assist interior comfortability; steeply pitched roofs for quick rainwater run-off; rhones (roof gutters) to harness the vast quantities of such rainwater, and the use of light-coloured paints to enhance thermal comfort within the buildings. The domestic typology - that which constituted the locus of much of the colonialist's activities - necessarily received major consideration in this regard (Fig. 6).

\subsubsection{Colonially facilitated building cultures}

Apart from their own direct intervention vis-à-vis the builtscape, the British were responsible for creating the enabling milieu for other cultures to intervene, architecturally, in Nigeria. With the arrowhead they constituted in the abolition of the obnoxious Slave Trade, it is not surprising that they were also in the vanguard of repatriation of former slaves. Slaves who had formerly worked in Britain were taken back to Africa, where the British settled them in Freetown, Sierra Leone, in 1807. However, many of them, convinced of their Nigerian ancestry, agitated until they were eventually brought to Lagos. Locally, they became known as saro (pidgin for their real name) and specialized in a building type very similar to that characteristic of the British occupation; additionally, the saro archetype featured fretwork at eaves and carved fascia-boards (Fig. 7).

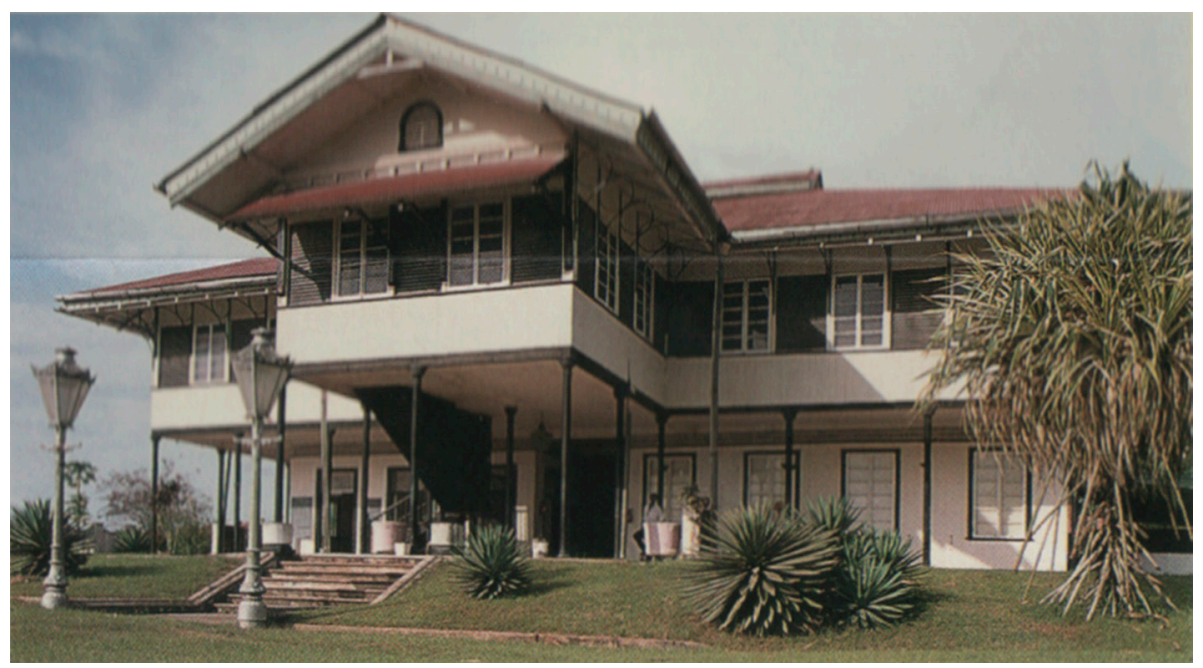

Figure 6: The Residency (Old Consulate), Calabar, 1883. (Source: LEGACY, 1999). 


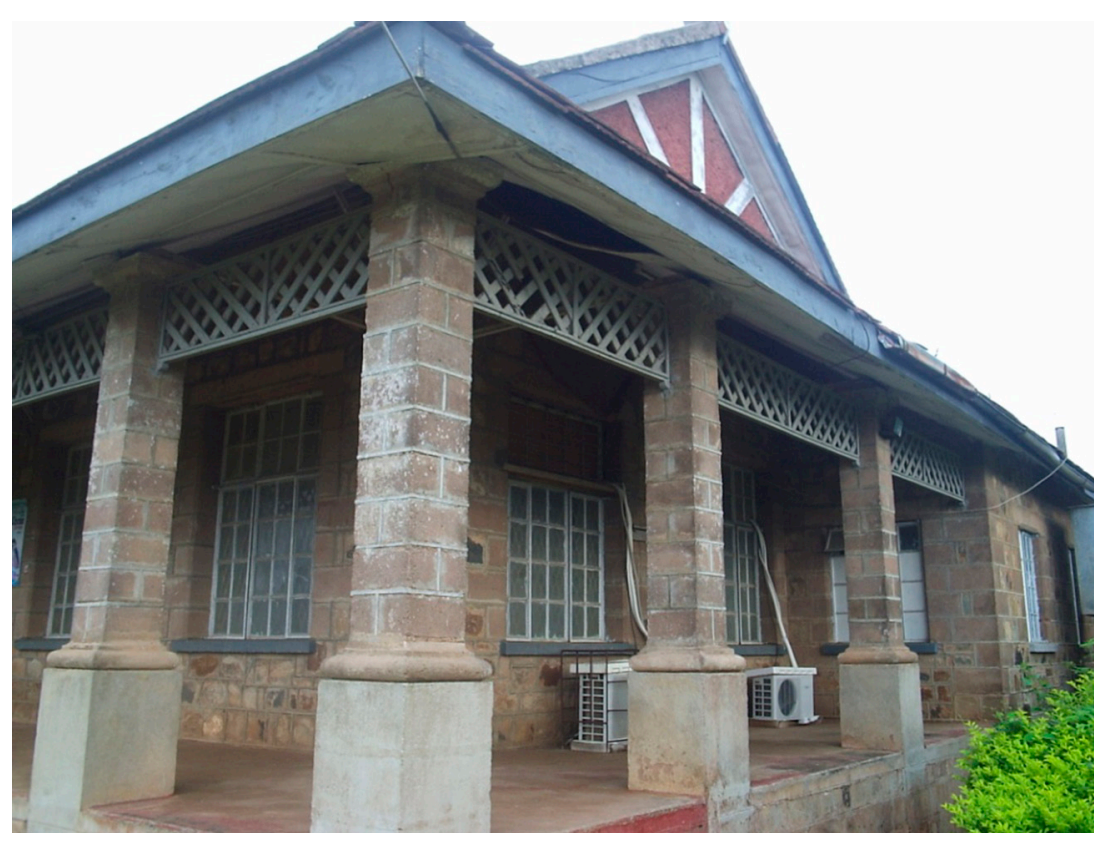

Figure 7: Saro-type bungalow, with framing veranda and timber fretwork at eaves. Modakeke, Ile-Ife. (C. O. Osasona, 2006).

The other group of returnee slaves to Africa who settled in Lagos, were the emancipadoes from Latin America (mostly from Bahia in Brazil, and from Cuba). Just as the saro established the 'Saro Quarters', these repatriated slaves founded the 'Aguda Quarters', building multi-storey structures that were known for heavy ornamentation and complex roof configurations incorporating the attic. In addition, the Brazilian style was characterized by a prominent central corridor, with the living spaces deployed to the left and right, and conveniences and other utilities as detached, ancillary structures behind the main building. Fired brick, well-seasoned hardwood and stucco were the favoured materials. The elaborate characteristic decoration was expressed as stucco artwork (on column capitals and bases, quoins, plinths/dadoes, door- and window-openings, balusters/balustrades and as relief murals), and also as carved work (turned timber posts, newels, handrails, door and window panels, and ventilation screens; see Fig. 8).

\section{ARCHITECTURAL CONSERVATION IN NIGERIA}

Despite the earliest concerns about preservation of Nigerian cultural artifacts and sites having begun during colonial times (with a National Museum already established in Jos by 1948), architectural conservation is still in relative infancy in the country. This is not because there is a dearth of buildings worthy of such attention; on the contrary, in every geo-political zone of the nation, buildings abound deserving of conservation, either on the grounds of age, historical associations or stylistic distinctiveness - generally acclaimed parameters for adjudging a building deserving of conservation [2]. As far from Lagos (the commercial nerve-centre and erstwhile national capital) as Ile-Ife is, the museum set up there by the National Commission of Museums and Monuments was already fully functional by 1954 . 


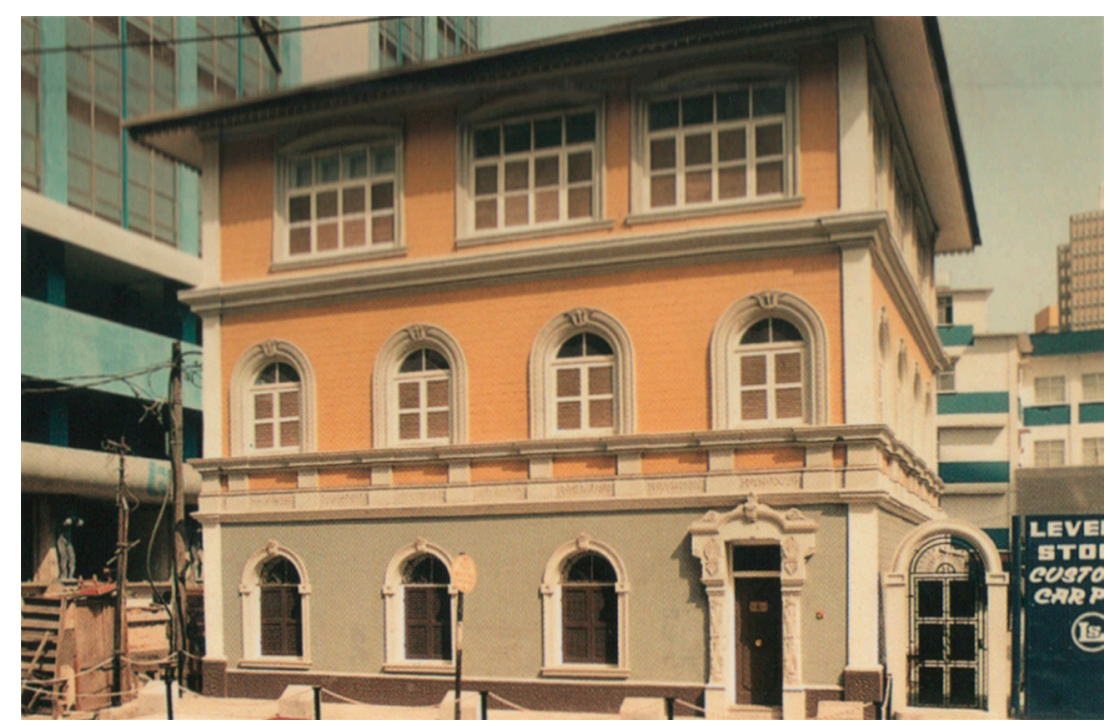

Figure 8: William Lumpkin House, ca. 1880. Abibu-Oki, Street, Lagos. (Source: LEGACY, 1999).

A national survey of historical sites was conducted by LEGACY (an environmental-interest, notfor-profit concern in Nigeria), in 1999. The project was sponsored by the Leventis Foundation (Nig.) Ltd., and with assistance (in terms of information) from the National Commission for Museums and Monuments (NCMM) and the Nigerian Conservation Foundation (NCF), it eventually produced the first comprehensive map to be published, showing the locations of the nation's heritage sites and how to get to them. Cumulatively, the map displays the geographic location of 48 national museums, 15 national parks and 129 historical sites. However, of the 129 historical sites indicated, only 47 are actual buildings, while just 27 of these are listed by the NCMM.

With an insignificant number (27) of listed buildings nationwide, it would be imagined that each one of these is receiving lavish maintenance attention; however, this is not strictly the case. Many of these heritage structures are indifferently attended to, in terms of conservation effort - a situation that is doubtless responsible for the low tourist appeal they command. In contrast to this, a good number of other heritage buildings on the LEGACY map, unlisted but under private patronage, are in commendable condition; some examples include Christ Church Cathedral, Holy Cross Cathedral and the Lumpkin House (Fig. 8). The first and second buildings are undoubtedly under the custody of thriving Christian missions that ensure their maintenance; a comprehensive restorative intervention on the latter - championed by LEGACY - was sponsored by the Leventis Foundation several years ago. As such, it would appear that private institutions are making more impact with respect to the phenomenon of architectural conservation in Nigeria than the government. While this is also true of many other nations (e.g. the UK, Italy and the USA) where architectural conservation is entrenched and outcomes well-acclaimed, the scenarios are quite different: elsewhere, architectural conservation is virtually a national culture such that individuals and corporate concerns view it almost as their community responsibility to invest in it and invariably consciously only assist the government (already with the political will but limited financial resources) to carry out this assignment. In Nigeria, architectural conservation is far from being a national priority; as such, the economic advantages have not been thoroughly researched, implying there is no incentive for the private investor to act upon, and no example to affect the individual's sensitivity and general disposition to such matters. 


\section{ARCHITECTURAL ICON - OR HOME?}

Doubtless, the statement 'a home is what you make it' is a well-known cliché and has been proved true, time and again. The difference between a 'house' and a 'home' is the meaning that that agglomeration of spaces (which would normally be called a house) connotes; i.e. the reading of a house - the individual or collective interpretation of its spatial configuration and inter-relationships - makes it a home. Apart from physical attributes, it has been argued that a 'home' is also a function of intangible variables such as love, companionship, acceptability and peace encompassed within it. So, in addition to physical factors such as location, aspect, internal partitioning, sizes of rooms, lighting, aeration, etc. (determining comfort and general liveability), human relationships within a building contribute to its transiting to a home - a place of comfort and overall well-being.

An architectural icon is a building imbued with symbolism. Usually, this would be because of socio-cultural significance or striking physicality, and it could be in contemporary or historical context. Thus, buildings that are seen as being symbolic, based on their being associated with an important event in the history of a people, qualify to be so regarded. Similarly, ancient buildings signifying the start (or full articulation) of a style - are indicated for such consideration, as they represent both longevity and continuity of a culture and also provide visual evidence of its architectural evolution. Other buildings could also be deemed iconic which, though not antiquated, display exceptional craftsmanship [3]. By these definitions, it would appear that an architectural icon is a cultural monument - something for community consumption, and to be set apart for conservation (and in the event of that breaking down, restoration), such that it is preserved as a legacy for posterity.

With the generic definition given above of an architectural icon, one would not normally expect it to be regarded as personal, domestic space - and thus appropriated. However, even in more urbanized settings, it is quite commonplace that a private iconic building (still essentially serving as home to the owners) could be opened up for public viewing. The dynamics of such an arrangement invariably entail deliberate planning such that, either just a part of the property is made available to the public or the whole is on display, but only for a clearly stipulated period of the year. In the former scenario, all-year family activities are not disrupted (as there is a clear dichotomy between the public commodity and home); in the latter, 'home', with respect to the owners (and in that particular setting) is only seasonal, and since the carefully scheduled timetable does not allow for any clashes, its sanctity is intact. Whichever approach is adopted, the tourism potential of such heritage buildings is significantly tapped. The situation in Nigeria is quite different; even tourism, as a general phenomenon, is in relative infancy (according to Ogundele [4], as a result of a weak organizational framework). Apart from the fact that (as mentioned above) only superficial attention is being paid to culturally significant buildings, what is increasingly becoming the norm is that one finds such (unrecognized, unlisted) buildings continuing to serve as routine domestic space. The following case studies highlight this local trend.

\subsection{Ologbenla House (1)}

Popularly referred to as Ile Oyinbo Moore ('the White Man's house along Moore Street'), this example of second-generation Brazilian (or more properly Afro-Brazilian) architecture is located at No. 55 Moore Street, about 500 metres (as the crow flies) from the Ile-Ife palace grounds (Fig. 9). The house is owned by a fourth-generation descendant of Balogun Derin Ologbenla, the regent-ooni of Ile-Ife, who directed the kingdom's affairs between 1878 and 1893, and was the 44th ruler in IleIfe history [5]. Specifically, it was built by Chief Moses Adekunle Ologbenla (the first child of Pa Daniel Adejumo Ologbenla, who facilitated the advent of Christianity to Ile-Ife, and who had also been instrumental to the establishment of Christ Apostolic Church, in the town). Another landmark 


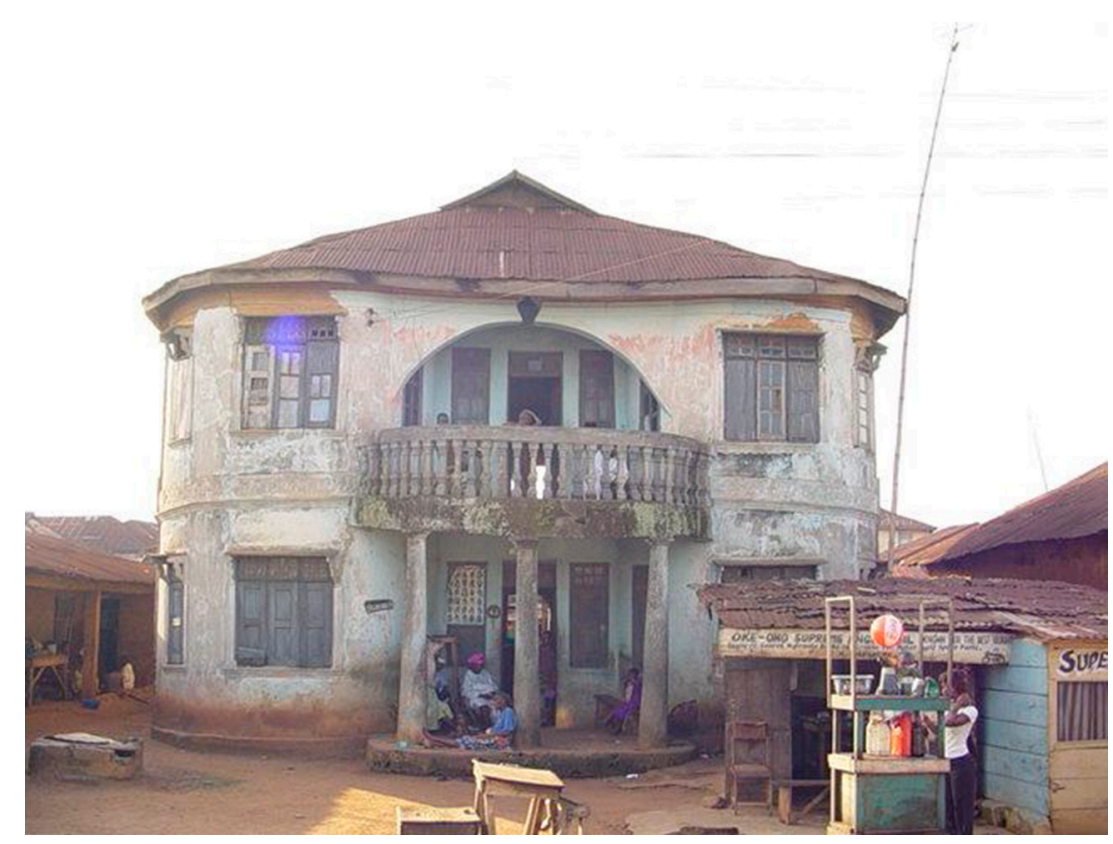

Figure 9: Ologbenla House 1. No. 55, Moore Street, Ile-Ife. View from the road. (S. Oluwole, 2003).

achievement of the dynamic Pa Adejumo was the fact of his having been the first person to use a tin roof (in 1912), in the whole of Ile-Ife - even before the reigning monarch; the novel feature was installed on top of a regular adobe bungalow. On his own part, Moses Adekunle Ologbenla (the builder of the house under study) also made his mark as a pioneer when, in 1949, he erected his personal residence along Moore Street, in the as-yet-uncommon Brazilian style - the first ever on that street. Later, his blood brother Michael Tunji Ologbenla decided to build his own house in a similar stylistic mould (the fashionable architectural style at the time, for educated Nigerians bent on making a social statement); he eventually erected the house at No. 53 Moore Street - Ologbenla House (2).

The native of Ife to whom the building under study owes its name, before eventually becoming the traditional ruler of Ife, had been a renowned warrior. According to family oral tradition, he had played a significant role in quelling a major insurrection in Ondo (where he had gone to assist the reigning monarch), dealing the rebel faction such a mortal blow that he was given the name ologbenla - 'he who is responsible for the big wound'. Because of political turbulence on his home front, when it came time for him to ascend the throne, Derin Ologbenla refused to be formally installed [6], choosing rather to administer Ife, for 15 years, from the hilltop safety of Oke-Igbo, a nearby settlement [7].

Chief Adekunle Ologbenla, the original owner of the building, had been a farmer and cocoa merchant by profession. He had the privilege of going to school, since his father was both wealthy and enlightened. He attended the locally famous St. Andrew's College in Oyo town and spent a good part of his young life in Oyo - and other places - before coming back to eventually settle in Ile-Ife. Largely due to his education, Chief Adekunle was a widely travelled man, and it must have been during his sojourn in Lagos that he saw buildings in the Brazilian style, which made him determine to build his own home in Ife, similarly. 
A second-generation classification has been accorded Ologbenla House (1), not for reasons of observed deficiencies or inferiority, but rather, for the fact that first-generation Brazilian-type houses were invariably only to be found in Lagos, the original base of Brazilian repatriates in Nigeria. Also, heavy ornamentation, a raised approach and complex roof configuration - typical of classical, firstgeneration models - are not present in its own design repertoire. In many significant ways, however, it is typical of the Brazilian style, with its centrally positioned passagio (passageway) and spaces one-room deep - deployed to both sides of it (see Fig. 10). Building materials and techniques are also typical: burnt brick, used to produce heavily massed walls and sand-cement plastered, hardwood timber for flooring, stairs, balustrades, door/window frames and roof trusses. Also, it features stucco decoration, expressed as brackets for window hoods, relief murals and balcony balusters. Significant too is the totally detached displacement of conveniences and the cooking area to the back regions of the compound.

Apart from the distinction the owner's pedigree automatically confers on the property, Ologbenla House (1) embodies appropriate and adequate significance for it to be treasured as an architectural icon. It marks the significant beginning of Afro-Brazilian architecture in Ile-Ife. In this regard, too, it is fast becoming a relic in the town, as sadly, quite a number of culturally significant buildings and sites are beginning to give way to 'modern structures' all across the town. It is strategically located in a part of town where any tourist interested in the material-cultural history of Ile-Ife (who has gone as far as the Ooni's Palace), would be interested in visiting it; specifically, it is on the cultural axis linking the Palace to Yemoo Grove - one of Ife's major historical sites, featuring a famous pottery museum and potsherd (St. George's) paving.

Presently, Ologbenla House (1) is in very bad shape (see Fig. 11 for details). As at the time of the fieldwork, it was occupied by an aged widow (the erstwhile youngest wife) of the house owner, with a few members of different generations of her offspring, as well as some paying tenants; certainly,
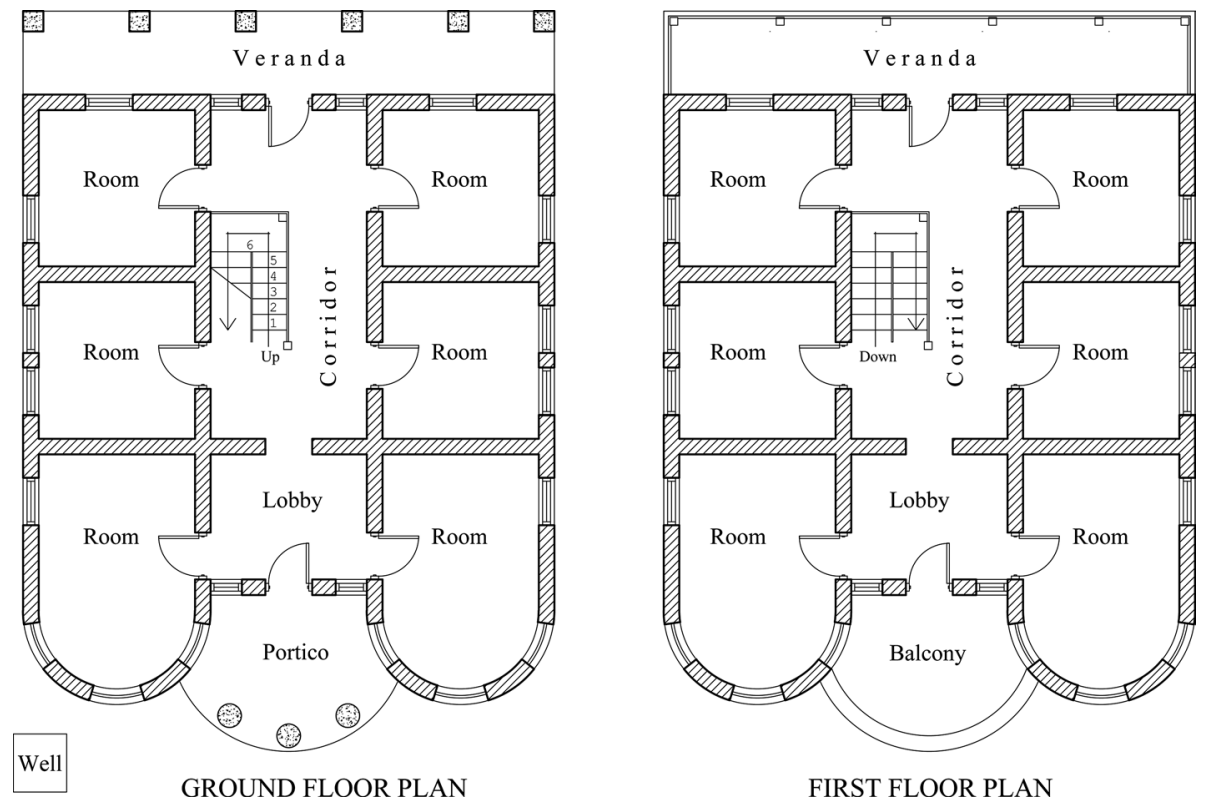

Figure 10: Floor plans of Ologbenla House 1: (a) ground floor; (b) first floor. (O. Oyeyipo, 2013). 


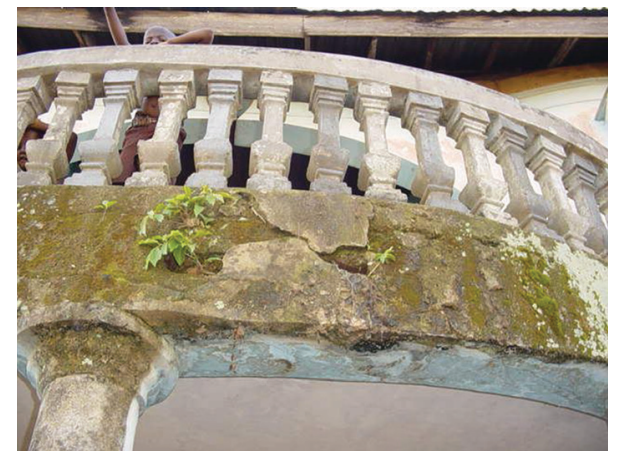

(a)

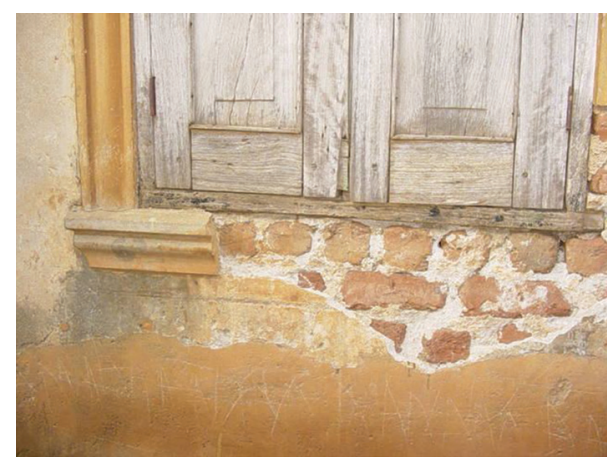

(c)

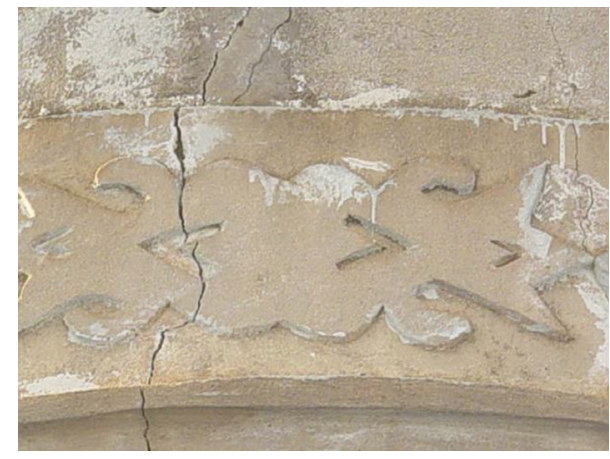

(b)

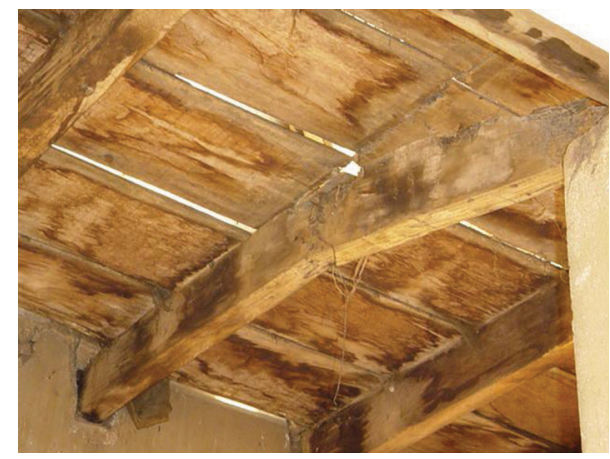

(d)

Figure 11: Evidence of decay: (a) stucco-work on base of balusters displaying growth of lichen, and chipping; (b) deep crack on external wall; (c) peeled-off plaster and moulding, exposing fired brick walling; (d) broken timber joist supporting external wooden floor. (S. Oluwole, 2003).

whatever rents are paid are far from being sufficient to provide even minimal maintenance for the building. Nevertheless, these people carry on with their daily lives, relatively secure and comfortable; all they see - and know - of Ologbenla House (1) is home.

\subsection{Ologbenla House (2)}

As previously mentioned, it also belongs to the Ologbenla dynasty and is specifically the family house of Chief Michael Adetunji Aderin Ologbenla, also a fourth-generation descendant of $\mathrm{Oba}$ elect Derin Ologbenla. It is located at No. 53, Moore Street - just next door to the former case study.

Michael Aderin Ologbenla, was a well-educated and successful Lagos-based civil servant, working majorly with the Nigerian Railway Corporation until his retirement. As his retirement plans got underway, he consulted some master builders in the Aguda Quarters of Lagos Island (who were essentially descendants of the original Brazilian repatriate slaves); they were able to furnish him with the design which, between 1953 and 1957 (when he actually retired), he implemented at No. 53, Moore Street, Ile-Ife (Figs 12-14).

An analysis of the physical characteristics of Ologbenla House (2) reveals that, apart from the issue of date (locating it many years after the first wave of Brazilian-type construction took place in Nigeria), some other features within its morphology position it several generations down the line. 


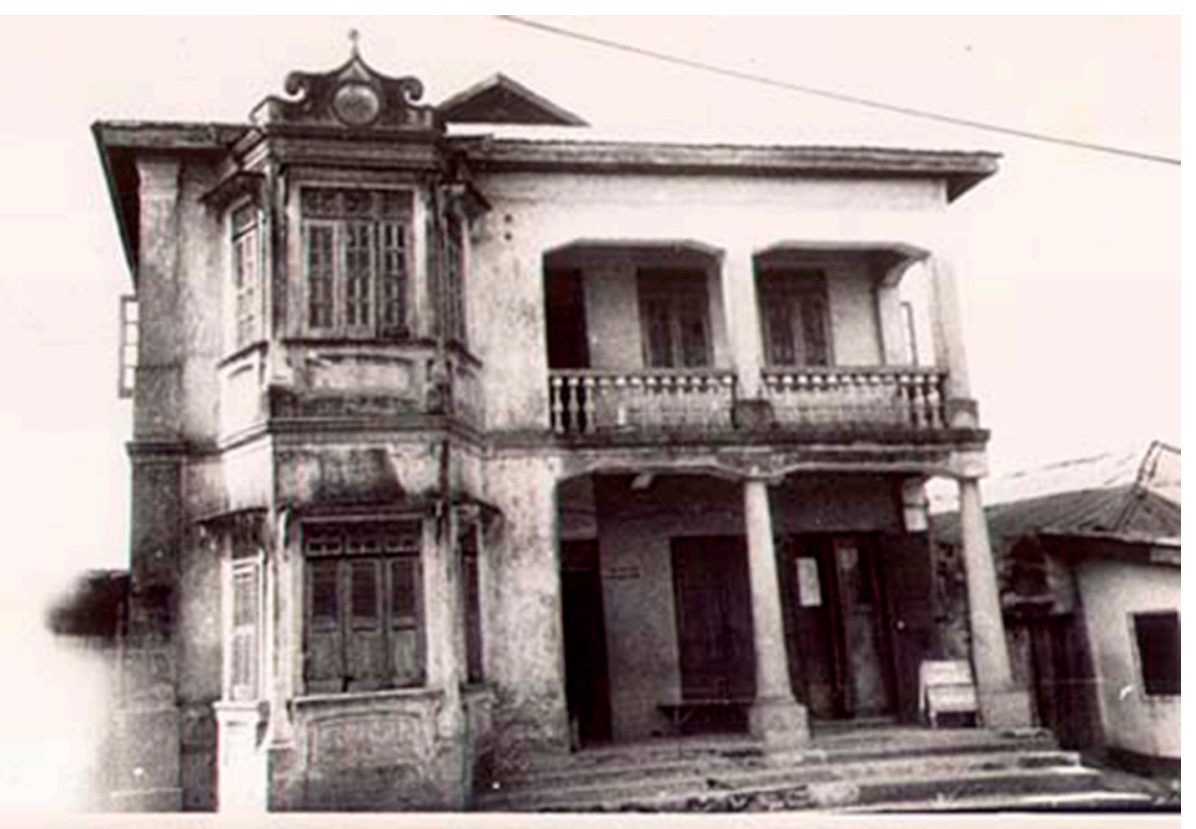

Figure 12: View of Ologbenla House 2, No. 53, Moore Street, from the road. (C. O. Osasona, 2003).

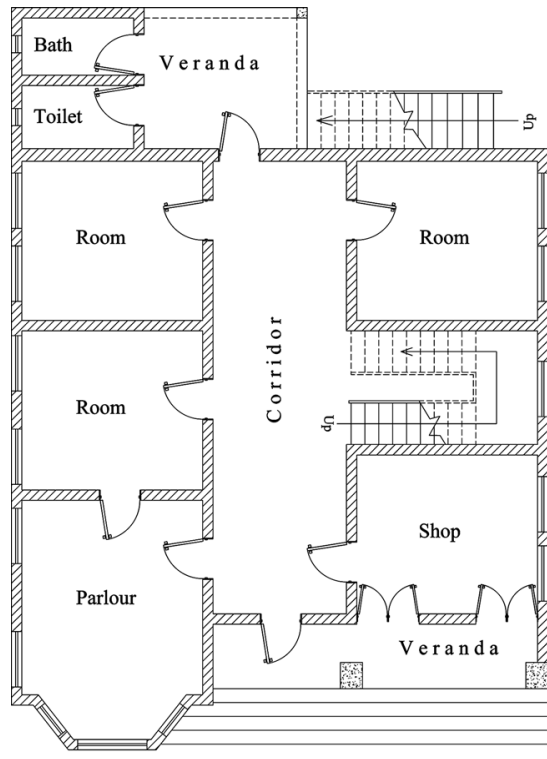

GROUND FLOOR PLAN

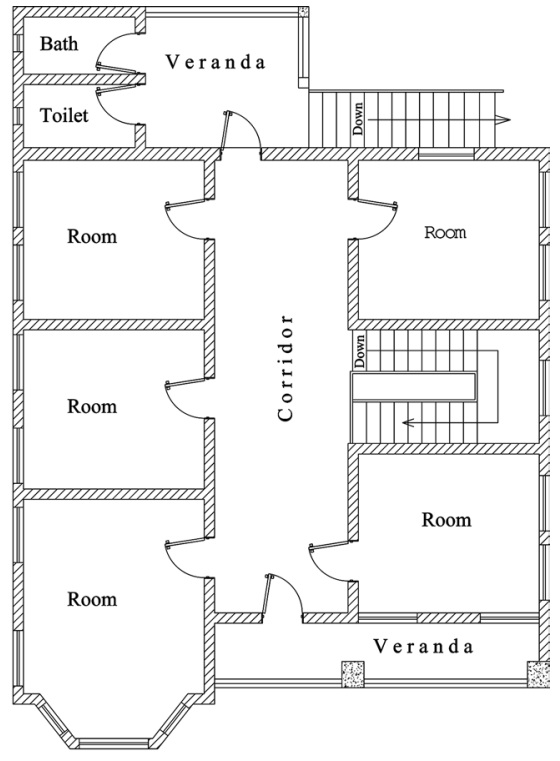

FIRST FLOOR PLAN

Figure 13: Ologbenla House 2: schematic of ground-floor plan. (O. Oyeyipo, 2013). 


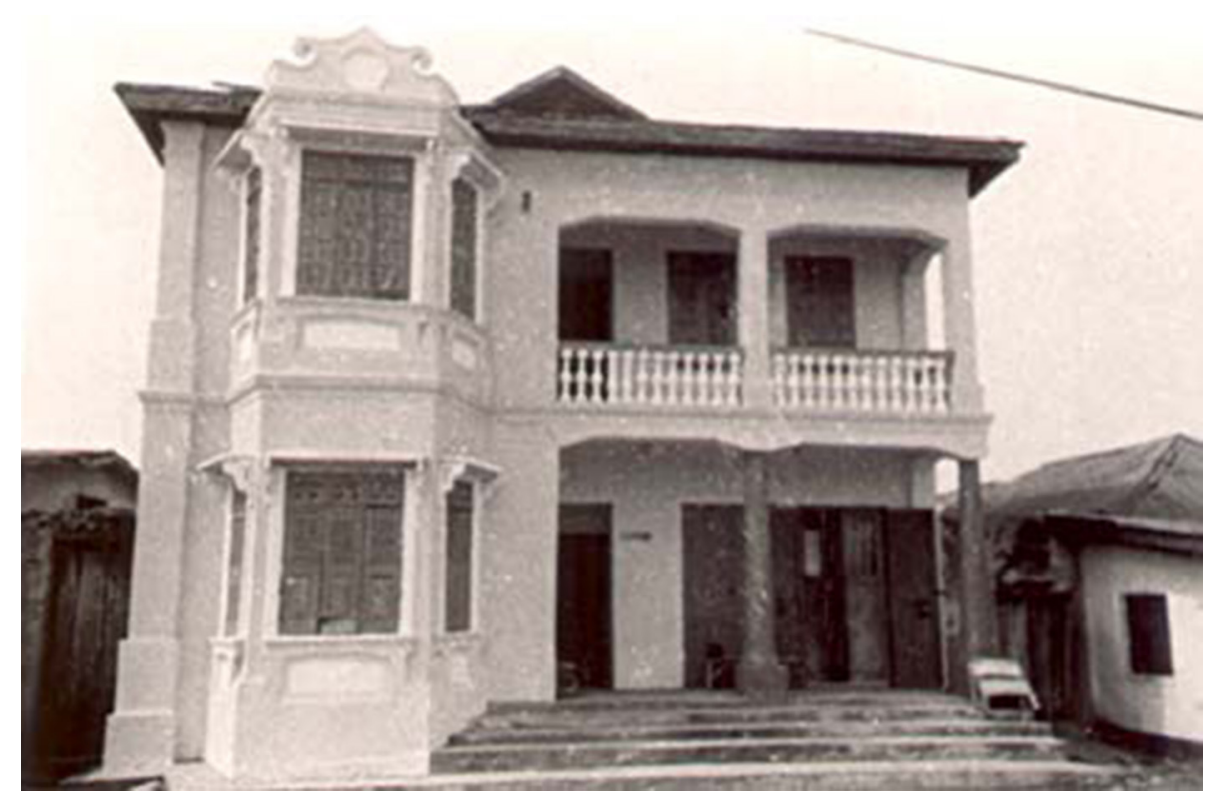

Figure 14: Ologbenla House 2, after the tentative restoration intervention in 2003. (C. O. Osasona).

Typically, the floor plan is characterized by an exaggerated, double-loaded corridor, running all the way from the frontage of the house to the rear quarters. Again, typically, construction materials are burnt brick for walls (rendered in sand-cement mortar), hardwood timber for door and window framing, internal stairs and balustrades, and stucco ornamental work on external walls. However, some significant points of departure are the inclusion of retail space in the frontage of the house, and a lateral deployment of the main staircase within the building (Fig. 13). Even if the presence of a 'business quarters' was a later modification (achieved by converting window openings in the front room to doors by which it is now directly accessed from outside), this services the 'living-andselling' disposition that only became increasingly manifested by Nigerians much later. Also, the fact of recesses (i.e. the verandas) being in the façade is atypical of first-generation Brazilian houses. Significant, too, is the fact that utilities (the cook-house and conveniences) were invariably detached in Brazilian houses; Ologbenla House has a semi-detached shower and toilet, while the kitchen retains a totally detached deployment. More significantly, it was the first house in the area to use a water closet system and integrate the toilet into the main house (albeit in a semi-detached manner; see Fig. 13).

Despite its apparent non-conformity with authentic Brazilian models, Ologbenla House (2) is architecturally historically significant for a variety of reasons. In the first place, apart from being only the second two-storey structure on Moore Street at the time of its construction, it was also the second building there displaying characteristics traceable to the Brazilian architectural style. Notable too, is its pioneering of the flushable toilet. Even the points of departure from the typical portray it as a harbinger of what has come to be the hallmarks of the vernacular in Nigerian architecture.

Today, though the ravages of time have left their marks on Ologbenla House (2) glaringly, it maintains an aura of distinction and cultural relevance. Faculty and students of the Obafemi Awolowo 
University, Ile-Ife, about six years ago, initiated restoration work on the building, hoping it would snowball into the heritage structure gaining attention for a more comprehensive intervention to take place; however, sadly, these expectations were never realized (see Fig. 14). Rather, the effects of the previous intervention have virtually all faded, while the parts that were overlooked then, continue their downward march to total dereliction - as a result of negligence, on the one hand, and genuine financial incapacity, on the other.

Despite the bleak picture painted of the current state of Ologbenla House (2), the house is very much lived in. Occupants include extended-family members of the original house owner, as well as paying tenants. The major respondent on this survey, Adeniyi Adelani Ologbenla (a great-greatgrandson of regent-ooni Derin Ologbenla), now deceased, lived there with his last wife and young daughter, at the time; he occupied a wing of the upper floor, while the rest of the 10-room building (and an ancillary structure at the back) was taken up by other individuals and small family groups. This multi-occupancy (or multi-habitation) status of the house is quite typical of the Nigerian city, where family houses play a significant role in alleviating urban housing shortage. On the ground floor, the room on the right flank of the building (opening out onto the veranda) has been rented out to a professional photographer-cum-videocamera man, for his business. Again, as previously inferred, this is contemporarily typical: the fully crystallized vernacular has as its most popular variant, one that integrates retail space in its configuration, as the average Nigerian either sells or buys things in a household context. Where sale of everyday items by a live-in tenant is not on a scale to warrant renting additional space, renting out such spaces to independent, non-resident tenants (as in the present case) - to optimize returns on the property - is quite common.

\subsection{Ile Alubarika ('House of Blessing')}

Located at No 13, Eleiyele Street (along the link road between Eleiyele and Oluorogbo Quarters) this building - even in its near-derelict condition - presents an imposing, delightful facade on this road (Fig. 15). Until less than 10 years ago, it made the greatest visual impact in its vicinity; that is, before Celebration Hotel (a multi-storey commercial concern) sprung up on the corner, gaining both locational and formal advantage over it.

Ile Alubarika was the property of an educated Ife cocoa merchant, named Adeyemi. By virtue of his business, he travelled extensively across the former Western Region of the country, and beyond. He married six wives in his lifetime - a fact that conditioned what he eventually built with the proceeds of his very successful cocoa trade. He took up residence in the house with his large family, late in 1970, and lived there for nearly 15 years, before his demise on the 24th of June 1984. The construction of the house commenced in the early 1960s, during the tenure of Chief S.L. Akintola as the Premier of the Western Region. Its construction witnessed some delay, due to the political upheavals that rocked the nation; it was finally completed around 1969. Its construction was carried out by indigenous masons and its Afro-Brazilian style was doubtless informed by Adeyemi's travels. On completion, it attracted the attention of some Ife-based foreigners who were ready to rent it from Adeyemi; however, he bluntly refused to hire it out, insisting he wanted to personally reside there with his family.

In its morphology, Ile Alubarika is quite basic: it is pronouncedly rectangular, along a northsouth axis and features the characteristic central corridor flanked by rooms on both sides. Again, utilities (covering conveniences and storage) are deployed as detached, back-of-the-house spaces, generating a service backyard for the compound. In typical Brazilian fashion, the staircase leading to the upper floor is embedded within the corridor; also, all building materials are 


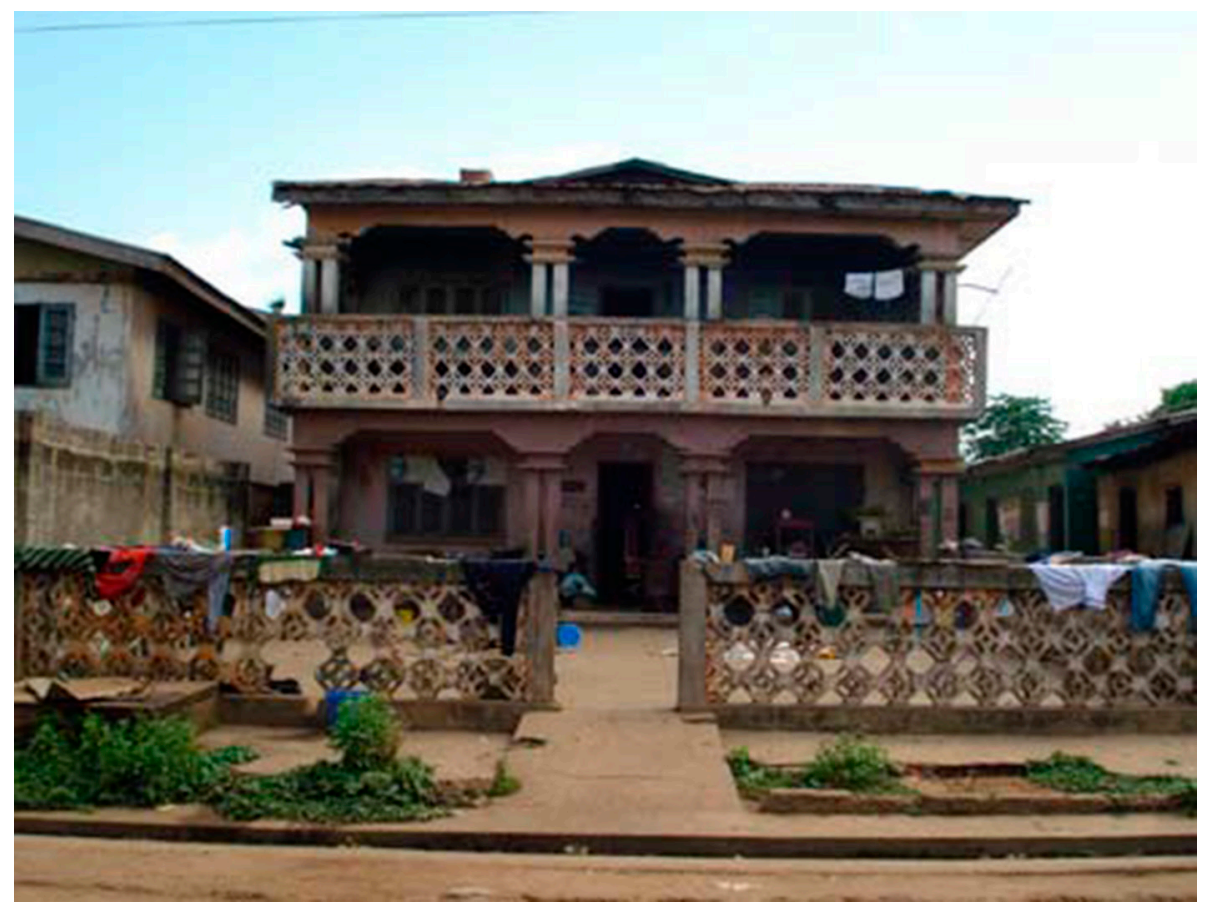

Figure 15: Ile Alubarika. View from the road. (A. Makinde, 2006).

typical - except for the perforated block finish to the upper veranda balustrade, a concession to the trend in the construction of such, at the time (see Figs 15-17). Despite its relatively young age (making age a non-issue as a criterion for justifying an investment in conserving/restoring the building), Ile Alubarika is architecturally significant in its own right. Clearly - and despite the fact of local artisans being used in its execution - it demonstrates high-quality craftsmanship. It is tastefully proportioned on the major facade, to offset the pronounced linearity on the flanks. In addition, the fencing of the premises signalled the genesis of a post-Civil War phenomenon that was soon to be commonplace in not just property delineation, but more significantly, security pro-activeness.

Like the earlier case studies, Ile Alubarika is in very bad shape, presently. The house is bedevilled by chipping off of chunks of masonry, heavy soiling, wood decay and roof-leaks (Fig. 17). Yet - in spite of these issues that should generate serious concern for the building's welfare - it is occupied. The youngest wife of the erstwhile house owner was in residence as at the time of the survey, with some grandchildren, as well as a few other members of the extended family and tenants. They carry on with their lives as best they can, engaging in various activities (such as petty trading) as a means of livelihood. In particular, here, one of the tenants makes a living out of commercial pepper-milling (see Fig. 20).

\section{PREDISPOSING CIRCUMSTANCES}

It has been established that, in the three cases of heritage architecture studied, the buildings - over and above their cultural significance - constitute structures where space has been appropriated 

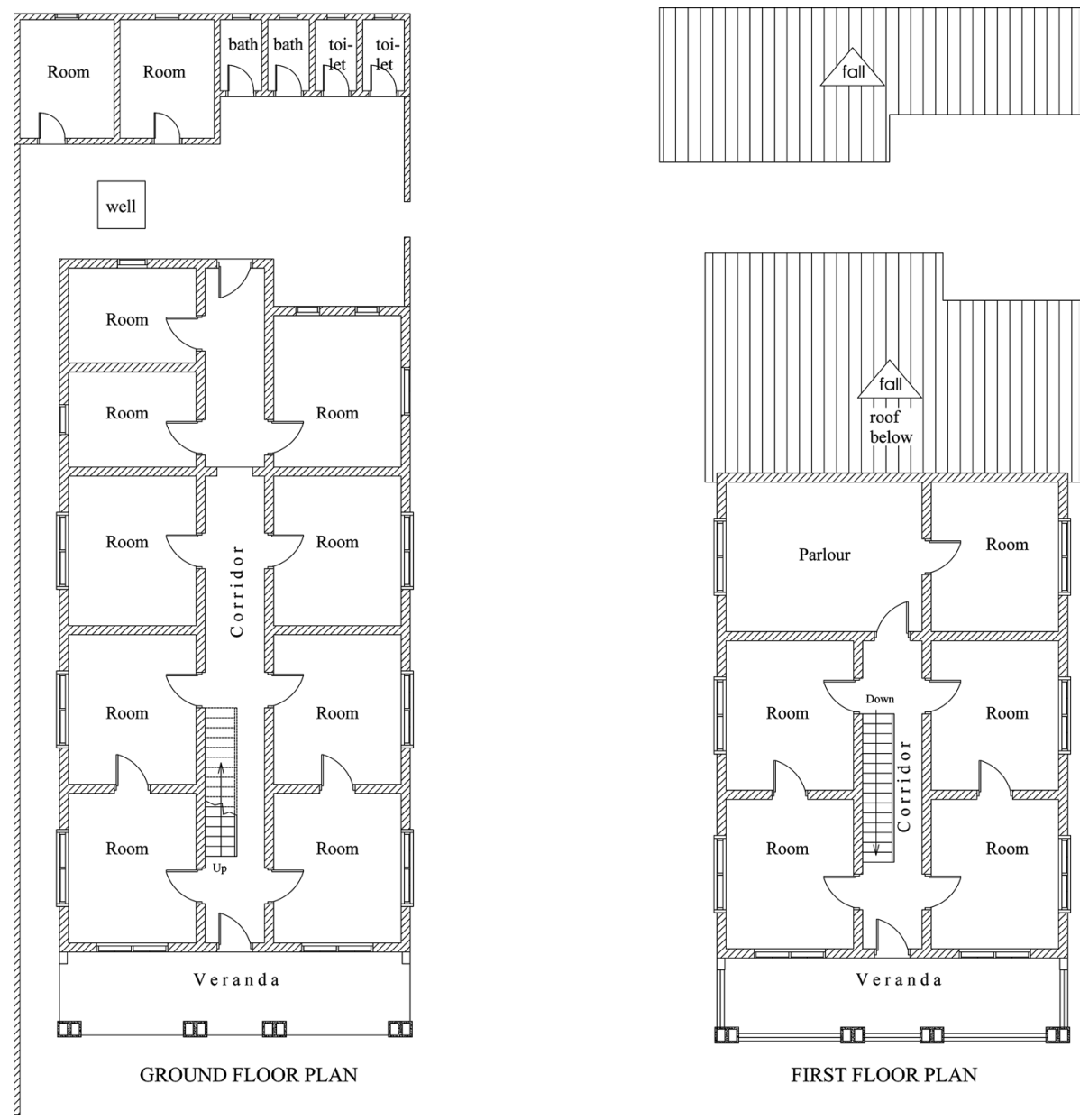

Figure 16: Ground- and first-floor plans of Ile Alubarika. (O. Oyeyipo, 2013).

and personalized majorly in a domestic context. Figures 18-20 attest to the fact that, despite the decrepit condition of these buildings, they are still home to several people, cutting across the different age-groups. Resident elderly family members contribute to the domestic set-up as babyminders (and general superintendents of older grandchildren), while more vibrant, younger family members coordinate tenant-related issues in the household. Regardless of public opinion and implicit (or conferred) community status, the residents carry on their daily lives as if their building were no different from their neighbours'; any real (or imagined) intrinsic value of their shelter is significantly lost on them. For the aged among the present occupants (who are in a position to recall the heyday of any of the buildings), the most they appear to do is to bemoan the passing away of such glory, and to philosophically conclude that the present dispensation has no use for such relics. Obviously, certain phenomena are responsible for such a state of affairs, and need to be considered. 


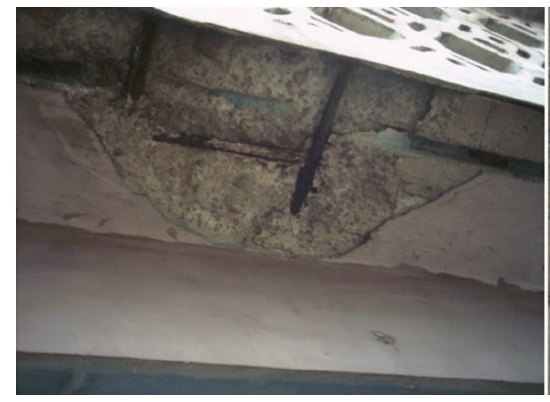

(a)

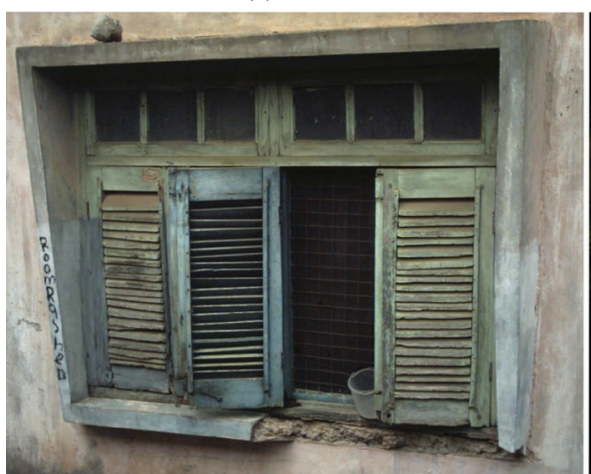

(c)

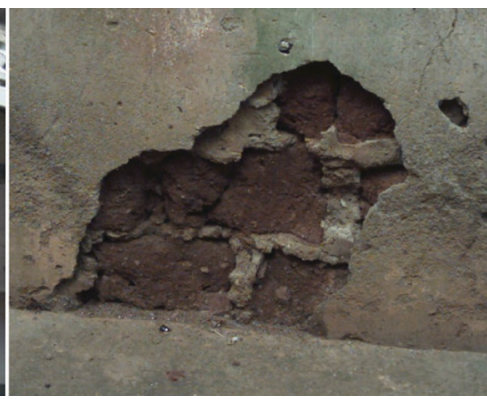

(b)

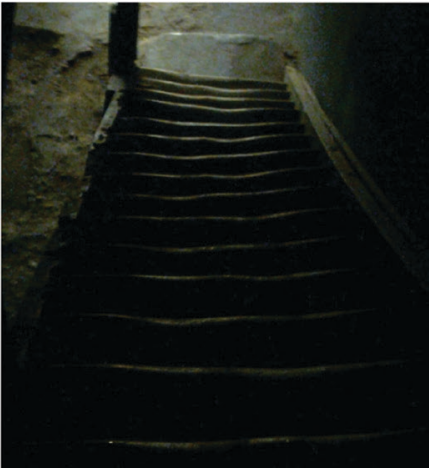

(d)

Figure 17: Decaying features on Ile Alubarika: (a) broken plaster work, exposing structural reinforcement on cantilevered balcony; (b) peeled-off plaster on wall, revealing typical fired brick core; (c) louvered timber shutters, with broken surround moulding; (d) worn wooden staircase; note broken floor screeding. (A. Makinde, 2006).

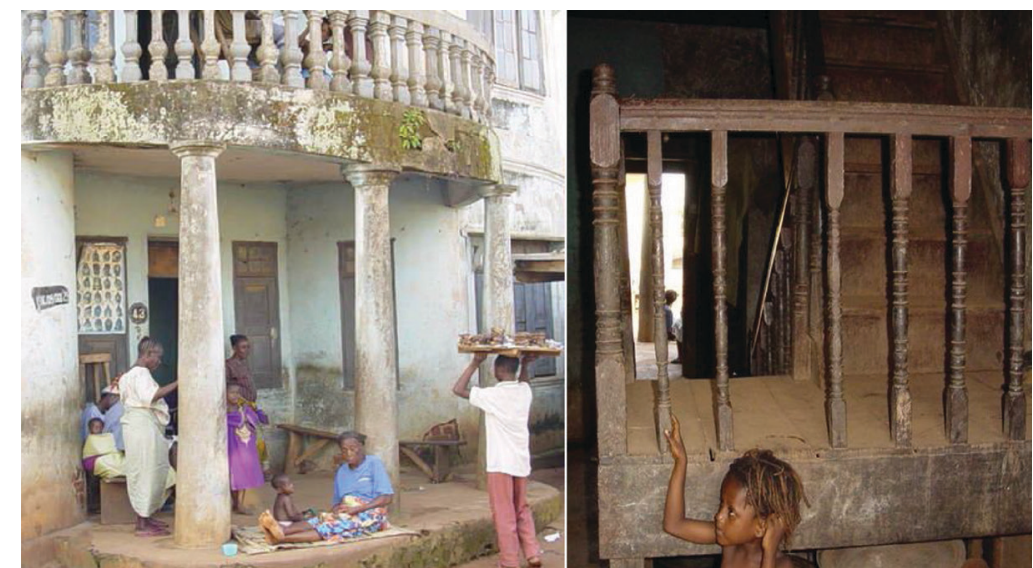

(a) (b)

Figure 18: Ologbenla House (1), as domestic space: (a) the porch is a place of relaxation, traditional hair-dressing and interactions with trades people, among other activities; (b) a little girl at home in the staircase lobby. (S. Oluwole, 2003). 


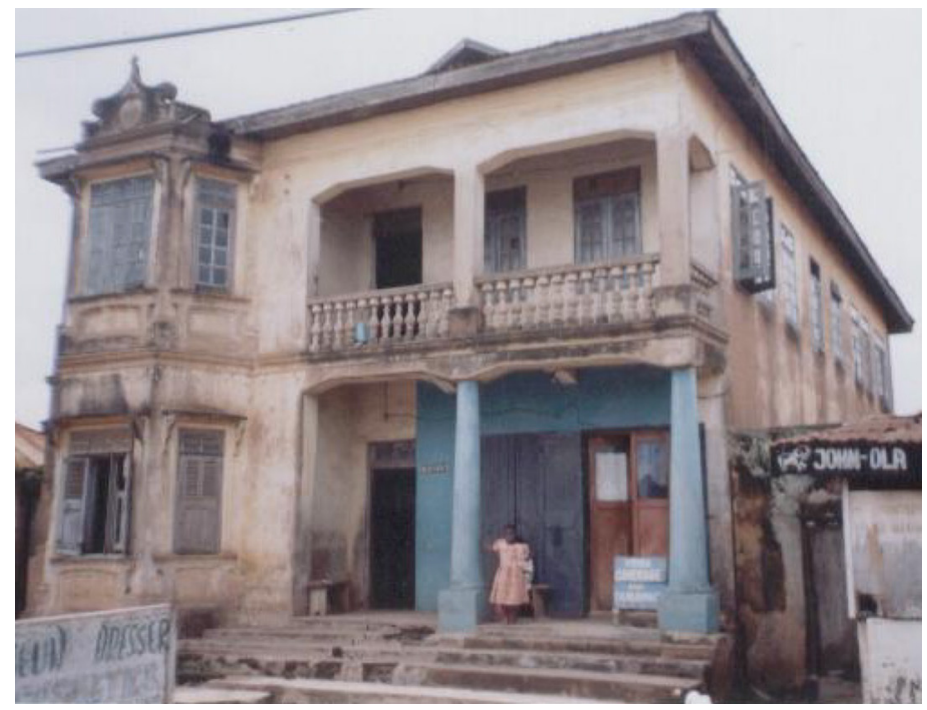

Figure 19: Ologbenla House (2) portraying 'living-and-selling': a little girl (who lives there) stands in front of the shop (right-hand side of the frontage) used by a professional photographer/ videocamera man. (A. Dimowo, 2003).

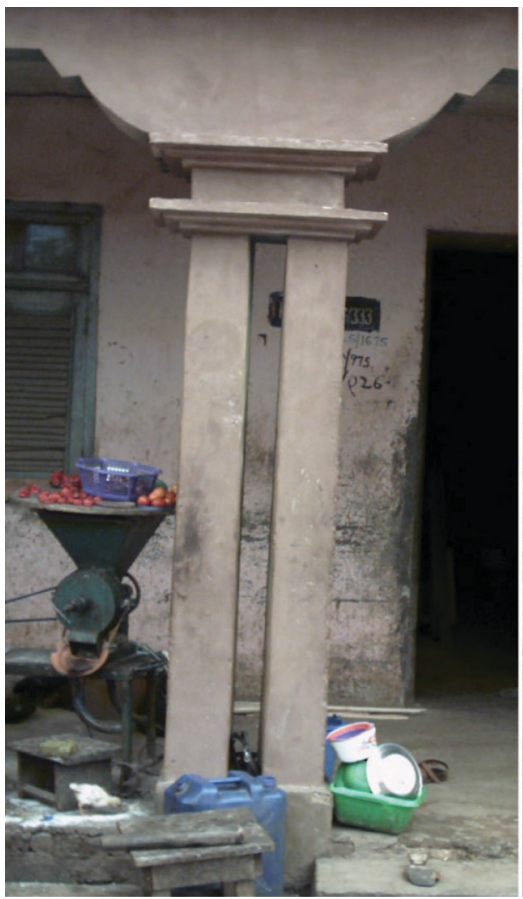

(a)

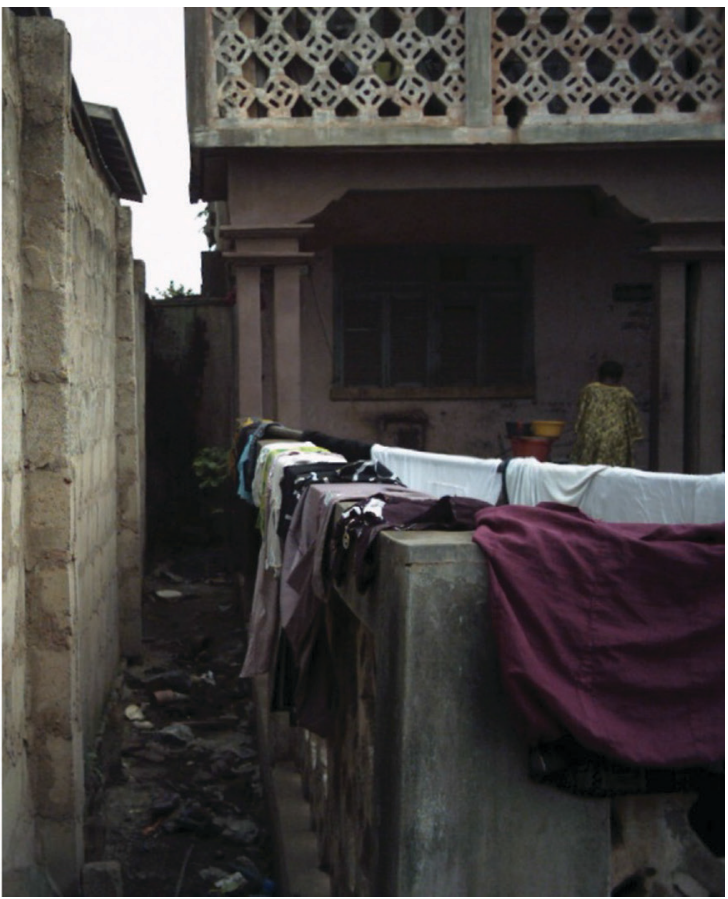

(b)

Figure 20: Evidence of domestic activity at Ile Alubarika: (a) commercial 'pepper-milling' on the veranda; (b) clothes spread out to dry on the perimeter fence. (A. Makinde, 2006). 


\subsection{The attitude of government}

That buildings considered heritage-grade should be left to perish (through corporate ignorance, sincere incapacity or criminal negligence) is far from being an ideal situation. It has already been cited in this work that, in Nigeria, only very few of such structures have been listed, and thus come under government patronage.

In developed countries of the world, architectural conservation receives greater attention than is the case in developing economies. Specifically, in countries like the UK, Italy and the USA, to mention a few, apart from the government dedicating a relatively sizeable part of the national budget to the conservation of cultural artefacts and monuments, it creates the enabling milieu for individuals and corporate concerns that have the financial wherewithal, to operate to complement its efforts in this regard. Additionally, by its direct interventions and policy statements, the average individual (and community at large) progressively has their orientation conditioned to cherish these relics, and commit - consciously or unconsciously - to their maintenance.

Generally, in the developed world, government is the chief custodian of a peoples' material culture. Responsible governments chart a sustainable course for the conservation of historical artefacts and monuments by putting various policies in place and generally facilitating their upkeep; civil society then responds appropriately. This response is multi-faceted: fundamentally (as mentioned above), a healthy sense of appreciation for such preserved works is developed, promoting a corporate psyche of community pride and an unconscious, instinctive commitment to their preservation; also, private individuals and corporate organizations who are financially capable support government initiatives by establishing societies that concern themselves with sponsoring conservation/ restoration interventions with respect to such monuments and artefacts. In specific terms, they provide funds for the restoration/renewal of such damaged heritage structures and also engage in activities that promote their conservation and general popularization. For instance, in the United Kingdom, agencies abound that were specifically set up to make grants available for the conservation of British heritage [8].

As previously stated, in Nigeria, the government is yet to significantly concern itself with such matters - for a variety of reasons. Since it became a nation-state, Nigeria has grappled with various issues, ranging from critical ones like overcoming a civil war, grappling with basic community health issues (such as polio-eradication), growing the economy and sustaining it in buoyancy, providing viable power for industrial and domestic use - right up to resolving intermittent religious and ethnic crises. With such survival-threatening issues on its priority list, perhaps one cannot justifiably castigate the Nigerian government for its apparent lack of foresight and general sensitivity, vis-à-vis heritage architecture. To compound the Nigerian situation, alternative sources of assistance are not just few and far between, but significantly also non-performing, due to their peculiar limitations: the organizations that have the passion (such as LEGACY) lack the financial muscle; those who do have the funds (invariably foreign concerns such as A. G. Leventis Foundation), for policy and logistic reasons, cannot commit fully to the Nigeria project.

\subsection{Socio-cultural relevance}

The symbolism of heritage architecture is seldom in the sustainability of its contemporary utilitarian (or even cultural) value. More often than not, it lies in an ingrained disposition to leave a tangible legacy to posterity - essentially for reasons of cultural continuity. As banal as it may seem, an architectural relic may be preserved in a given location merely to provide visual relief; it may be just to break the monotony of a landscape of frequently monumental and oppressive ultra-modern 
structures - sometimes generating serendipity [9]. Additionally, the survival of a high proportion of old buildings provides a sense of permanence - 'anchorage' - since they convey 'a sense of stability and repose' [10] to the community. Even in economic terms, well-maintained heritage buildings are virtually priceless as, apart from their symbolic value, they are invariably an embodiment of sound building sense (having stood the test of so many years of weathering without collapse), and representing time-tested techniques, and thus, genuinely valuable investment in contemporary times. Harvey condemns the 'progressive reduction of this asset by demolitions' as 'not only a crime against humanity and taste, but also spendthrift folly leading towards bankruptcy' [11].

Quite apart from government's failings, the Nigerian populace carries a significant part of the burden of blame for the neglect that is robbing the nation of prime heritage architecture. Over the years, it has been observed that progressively, the mind-set of the average Nigerian has been to associate most cultural phenomena with 'backwardness', and to rush, headlong, into an acceptance of anything that appears to connote an integration with - and acceptance of - the global culture. Hence, 'modern' is the watchword, and 'universal' is the attitude. With specific respect to architecture, traditional materials and layouts have long been denigrated, and even culturally symbolic spaces like the akodi have been undergoing transformation for quite a while, now [12]. Using the Ife akodi as an example of this paradigm shift, it is observed that this concourse for family meetings (which was traditionally an extended-family rallying point, given pride of place in the impluvium-courtyard house type) - as a result of this pandering after modernity - has now been totally 'extracted' from the family house left in the throes of decay, and 'celebrated', as an independent structure on adjacent family land; a case in point is Ile Obaloran, at Iloro in Ile-Ife (where the akodi is now a two-storey building [13]). The tragedy in this 'development' is not the physical dislodgement of the akodi, so much as the moving out of its cultural symbolism with it; in such instances, the akodi is now little more than an events hall. Conclusively, even in the minds of the people, buildings with heritage significance are regarded as having outlived their usefulness. With such a prevalent attitude, people who have had no choice but to stick with their heritage-status family houses are bound to fail to understand that it has significance beyond that which they confer on it as their home, i.e. the locus of their daily existence.

From a totally different perspective - that is, one based on considerations of the steadily climbing unemployment figures (either as a result of never having been in employment, or being laid off) investing in dilapidating, dated structures (with no apparent market value) - is understandably far from the thinking of the generality. At the level of the extended families that actually own these structures, such economic (and other social) considerations could account for the neglect: the younger generation(s) to whom these various heritage properties appertain, no longer reside in IleIfe (and other not-too-urbanized towns where similar structures are located); they have gone to the big cities, in search of well-paying jobs, and while they are still trying to find their feet (and even when they do become affluent), do not see the need to have such 'relics' constitute albatrosses about their necks, or otherwise drain their financial resources. For the few in the diaspora who have sentimental attachment to these buildings (as 'home'), it is still not good enough reason to invest heavily in their maintenance: they are useful as a place of overnight (or, at most, a few days) stay, in the event of a social function bringing them back to Ile-Ife; hence, the need to invariably ensure that a member of the family is still in residence there (rather than renting the property totally out to paying tenants). This social 'pull-factor' (i.e. the infrequent socially motivated visit) is sometimes the basis for occasional touch-ups some such heritage buildings could receive; the commonest such function is a funeral of an important member of the family. These social events are the very reason some such buildings are still enjoying a lease of life. Sadly, several - notwithstanding - have already been 
overwhelmed by seemingly greater priorities in land matters and have been destroyed. As recent as May 2013, Ile Akogun, the official residence of Ile-Ife's traditional 'Field Marshall' [14] was bulldozed, to make way for a 'modern' building.

\subsection{Perception as a conditioner of space appropriation}

With the scenario of aged women and grandchildren in an extended-family situation being left to see to the welfare of the house (as architectural structure), it is not surprising that very little is actually done for the building's upkeep. A popular Yoruba adage posits that others will call something that belongs to you the name you give it. What the adage seeks to convey is: your perception of what belongs to you (in terms of its utility or other values, and the respect you thus wish to accord it) will determine how you present it to others, and, in consequence, the deference they will accord it. To the extent to which you bestow honour on it (deserving or otherwise) - by selectively using it, and for special things - to the same extent will others treat it with respect. Relating this to the matter at hand, since the occupants of the houses under study, perceive of these structures purely as 'home', it will be extremely difficult to try and infuse any sense of awe (or peculiar regard) into them, with respect to their appropriation of such structures; to them, they constitute home - and they are living there as such. If the owners of the heritage property under discourse have a perception of it beyond their 'family house', it might have conditioned their attitude to its maintenance. However, the disposition is quite different; where the issue of the building's style is not totally lost on them, the attitude is either one of indifference (as, after all, a building must follow a design), or one of silent chafing that, in the present dispensation where 'modern buildings' are springing up around them (many being built by natives in the diaspora, to make a social statement back at home) they are saddled with a relic that constitutes a white elephant. So, by and large, the perception of most of the users of these samples of heritage architecture is that it is domestic space, accommodating their lifestyle and defining their identity.

Closely allied to the phenomenon of perception (as a factor responsible for the neglect of heritage structures) is the issue of genuine financial incapacity. Apart from Ologbenla House (2) (where the key informant was a male family member), all the occupants who are major stakeholders were female; where there were other male occupants, they were paying tenants who, understandably, had no sentimental attachment to the respective houses and could not much care how outsiders perceived of the property. As such, even for reasons of routine maintenance - and since, culturally, that is not a female's area of responsibility - the predisposition to do more than keep the building from falling totally apart, was not a major consideration.

\section{SUMMARY}

This study has attempted to outline the sources of Nigerian heritage architecture. Specifically, it has critiqued three samples of these from Yoruba land, all located in Ile-Ife. Table 1 sums up the findings with respect to these buildings. All three have been identified as being significantly patterned after the Brazilian style, and it has been established that Ologbenla House (1) is the most typical of the three, being closer to the original models than the others. While Ile Alubarika is the most recent (displaying new trends in complementary elements just gaining prominence in its heyday), Ologbenla House's (2) major significance is highlighted as being its pioneering status vis-à-vis heralding a tenuous integration of conveniences into the main building, as well as portraying the signal provision made to accommodate the living-and-selling predisposition of Nigerians - a major defining characteristic of Nigeria's typical vernacular, touching the very soul of how Nigerians really want to appropriate domestic space. 


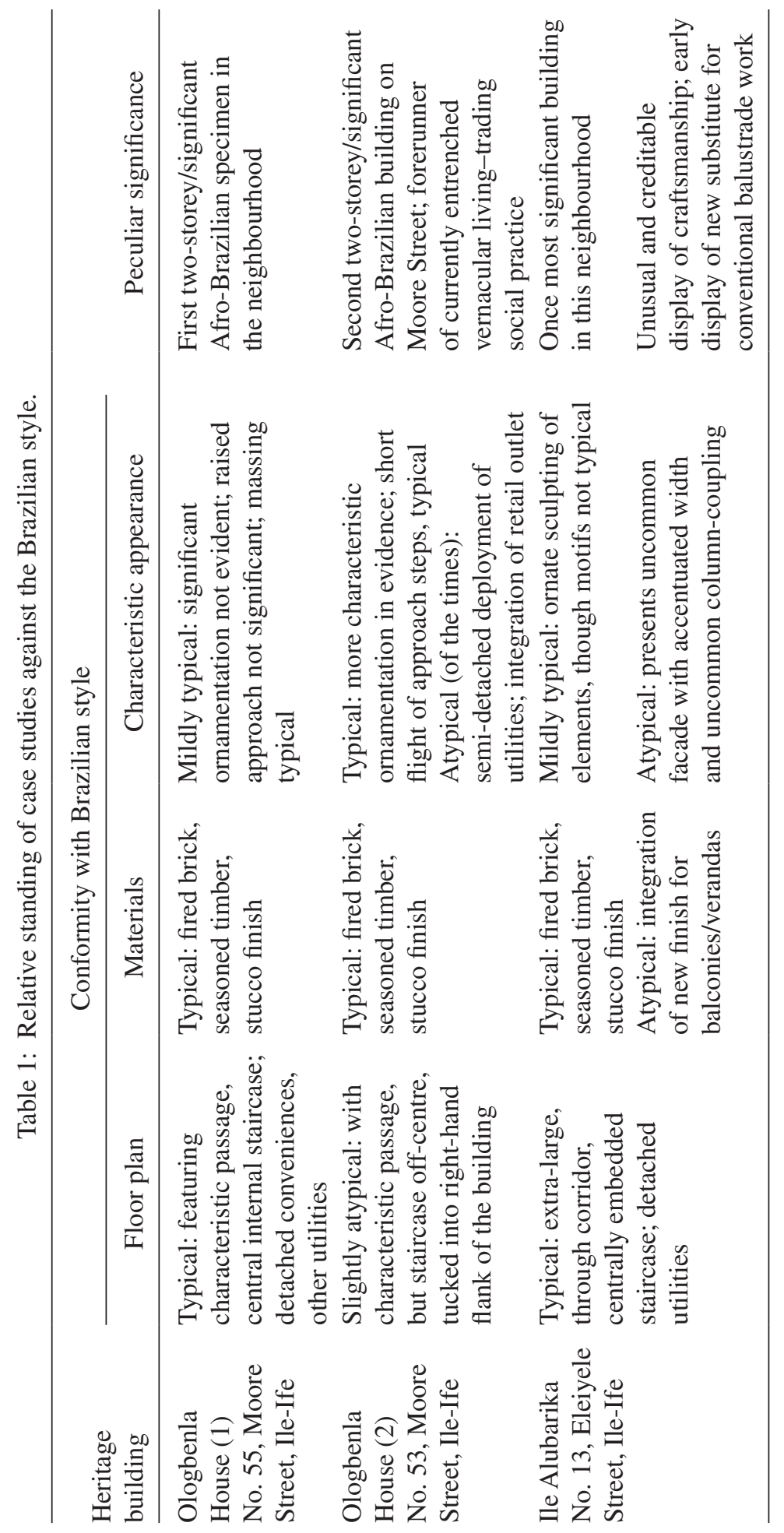




\section{CONCLUSIONS}

Various approaches have been adopted over time and in different climes, for the maintenance of heritage architecture, each as valid as the other - provided it accomplishes the purpose of ensuring the preservation of the structure for posterity. Whether this happens in the context of the building being categorized as purely an icon (to be viewed, as in a museum setting) or as icon-cum-home (again to be viewed and relished as a work of cultural value, but also to be lived in, made 'alive', and treasured as a personal reference point), the non-negotiable end result should be the survival of the structure in the best possible condition. In the event of heritage architecture being treated as a community icon, a dedicated agency is usually responsible for its maintenance. The cost of doing this is significantly offset by opening it up to the public for viewing, at a fee. Where the original house owners exercise their ownership rights over the building, expectedly the maintenance of their property is their responsibility; however, where they open it to the public for a financial consideration, again income thus generated goes a long way in alleviating the financial burden of its maintenance, to them.

In the Nigerian context, there does not appear to be a middle-of-the-road course, whereby it is feasible for heritage architecture to thrive as both icon and home. The undeveloped state of architectural conservation/restoration in the country is responsible for this, continuing to make it an 'either-or' scenario (whereby a building might qualify for official upkeep if it is listed, and if not, it continues to be the responsibility of its owners - who do not see it as anything else but their home).

\subsection{The way forward}

Considering the socio-cultural context, the Nigerian 'ideal' (vis-à-vis the 'icon' or 'home' debate), appears to be an embracing of both - a fusion of the consciousness of the cultural significance of heritage architecture and its appropriation as domestic space, by legitimate family house owners. The general rationale for this position is multi-faceted: in the first place, no-one can be left in doubt as to the government's incapacity to adequately cater for these monuments; either as a result of a lack of the political will or the ready means to do so, it is glaring that it is not on top of the situation. On their part - as ramshackle as many of these buildings appear to be - they are providing accommodation for certain people in a semi-urban setting - implying that, albeit in limited measure, they cushion the impact of housing shortage in such locations; additionally, apart from the truism of senior citizens associated with such buildings still needing a place to stay, the familiar socio-physical settings of such buildings give these aged residents social bearing, and eliminate anomie - essential ingredients for their psychological and overall well-being. Lastly (and has previously been discussed), such residential heritage architecture provides adequate social anchorage for family members in the diaspora, i.e. a place of recourse for functions within the town and its environs - a rallying point for family confabs.

In the light of the foregoing, it is strongly recommended that heritage architecture in the custody of family members should remain so. However, they should be given the necessary incentive - in terms of briefing, financial and other support - to not only change their perception of these monuments but also empower them for sustainable maintenance of such. With this meeting together of the major interests involved, a reasonably bright future for such endangered heritage architecture may be guaranteed.

\section{REFERENCES}

[1] Fajana, A., The background to colonial rule. From Colony to Sovereign State: An Introduction to the History of West Africa Since 1900, ed. A. Fajana, Thomas Nelson \& Sons Ltd.: Middlesex, 1979.

[2] Pearce, D., Conservation Today, Routledge: London, 1989. doi: http://dx.doi.org/10.7202/ 1017569ar 
[3] Harvey, J., Conservation of Buildings, John Baker Ltd.: London, 1972.

[4] Ogundele, S.O., Tourism development in Nigeria: agrassroots perspective. Cultural and Eco-tourism Development in Nigeria, ed. A. Aremu, Hope Publications: Ibadan, p.113, 2001.

[5] Akinjogbin, I.A., Ife: the years of travail, 1793-1893. The Cradle of a Race (Ife from the Beginning to 1980), ed. I.A. Akinjogbin, Sunray Publications: Port Harcourt, p. 116, 1992.

[6] Akinjogbin, I.A., Ife: the years of travail, 1793-1893. The Cradle of a Race (Ife from the Beginning to 1980), ed. I.A. Akinjogbin, Sunray Publications: Port Harcourt, p. 148, 1992.

[7] Akinjogbin, I.A., Ife: the years of travail, 1793-1893. The Cradle of a Race (Ife from the Beginning to 1980), ed. Akinjogbin, I. A., Sunray Publications: Port Harcourt, p. 157, 1992.

[8] Cooling, P., Shacklock, V. \& Scarrett, D., Legislation for the Built Environment: A Concise Guide, Donhead Publishing Ltd.: London, pp. 236-248, 1993.

[9] Osasona, C.O. \& Ewemade, F.O., Ile Timi: the interface between traditional and vernacular architecture in Ile-Ife. STREMAH 2011, Wessex Institute of Technology: Southampton, p. 113, 2011. doi: http://dx.doi.org/10.2495/str110091

[10] Harvey, J., Conservation of Buildings, John Baker Ltd.: London, p.18, 1972.

[11] Harvey, J., Conservation of Buildings, John Baker Ltd.: London, p. 20, 1972.

[12] Mills-Tettey, R., The layout and transformation of some traditional Yoruba compounds at Ile-Ife, Nigeria. Studies in Environmental Design in West Africa, 2, 1992.

[13] Osasona, C.O. \& Ewemade, F.O., Ile Timi: the interface between traditional and vernacular architecture in Ile-Ife. STREMAH 2011, Wessex Institute of Technology: Southampton, pp. 101-102, 2011. doi: http://dx.doi.org/10.2495/str110091

[14] Osasona, C.O., Ogunfolakan, B.O. \& Ewemade, F.O., The renewal of Ile Akogun in Ile-Ife, Nigeria: aparadigm for the conservation of Yoruba Iconic Architecture. Africa Habitat Review, 4(4), The Journal of the School of the Built Environment, University of Nairobi, Kenya, pp. 225-238, 2011. 